Hydraulic Behaviour of Estuaries 
Civil Engineering Hydraulics Series

General Editor: E. M. Wilson

Professor of Hydraulic Engineering, University of Salford 


\title{
Hydraulic Behaviour of Estuaries
}

\author{
D. M. McDowell and B. A. O'Connor
}

Simon Engineering Laboratories, University of Manchester 
C) D. M. McDowell and B. A. O'Connor 1977 Softcover reprint of the hardcover 1st edition 1977

All rights reserved. No part of this publication may be reproduced or transmitted, in any form or by any means, without permission

First published 1977 by THE MACMILLAN PRESS LTD London and Basingstoke Associated companies in New York Dublin Melbourne Johannesburg and Madras

ISBN 978-1-349-01120-9 ISBN 978-1-349-01118-6 (eBook) DOI 10.1007/978-1-349-01118-6

This book is sold subject to the standard conditions of the Net Book Agreement 


\section{Contents}

PREFACE

vii

1. A GENERAL DESCRIPTION OF ESTUARINE BEHAVIOUR

2. HYDRODYNAMICS OF ESTUARIES 30

3. MIXING PROCESSES 48

4. SEDIMENT MOVEMENTS 83

5. THE STUDY OF TIDAL SYSTEMS: FIELD MEASUREMENTS

6. THE STUDY OF TIDAL SYSTEMS: MATHEMATICAL TIDAL MODELS 146

7. THE STUDY OF TIDAL SYSTEMS: WATER QUALITY MODELS

8. THE STUDY OF TIDAL SYSTEMS: HYDRAULIC MODELS

9. CONTROL OF ESTUARIES 225

10. DISCUSSION OF CASE HISTORIES 250 INDEX 


\section{Preface}

Estuaries are meeting places-of salt water and fresh water, of fresh-water and salt-water flora and fauna, of land-borne and sea-borne sediments, of seafarers. This complexity accounts for much of their fascination for people like the authors of this book, but it makes it difficult to study estuaries and to describe them in a single introductory volume. We have confined the book to the flow of water, salts and water-borne solids; that is, to the rather narrow view of physical behaviour that excludes flora and fauna. We realise that plant and animal life have an essential role in the physical behaviour of most estuaries, in colonising mud flats, in changing the character of fine sediments and, in warm climates, in determining the topography by growth of coral and cementation of shell debris. We have concentrated on the movement of water and its immediate effects. Our purpose has been to expose the mechanics of estuarine systems and to indicate the principal methods used to control them.

There have been many descriptions of estuarine behaviour, but all, including this book, have been limited by the power of words and the poverty of our scientific formulations. In most of them, an 'if only...' approach has been used. The estuaries have been straightened and their cross-sections deformed into neat shapes while the water has been homogenised or, as a concession to reality, stratified in an attempt to make the physical processes manageable. An optimistic view has been taken of such complexities as sediment transport, use being made of equations that do not work at all well even for the unidirectional flow situations for which they were designed.

In this book, we have tried to give an honest account of how real estuaries behave and to show how they might be managed. Underlying the whole book is a description of the interaction of the many physical factors. Much of this can be read and understood without any knowledge of advanced mathematics. Inevitably some chapters are based on mathematical equations. Summaries of these have been provided so that the non-mathematician can see what can be achieved by mathematical tools.

Chapters 1, 5, 9 and 10 give an account of estuarine behaviour; of the care that must be taken in trying to measure it quantitatively; of methods of estuarine management by engineering work; and of the response of several actual estuaries to control work. These can all be read without much 
specialised knowledge. The other chapters are concerned with mathematical formulation of the behaviour of real estuaries and with aids to solution of real problems using physical and mathematical modelling techniques. We have tried to describe the physical basis of each technique and to demonstrate its use and limitations in dealing with real situations.

We consider that, in an introductory book such as this, it is more important to present a global view of estuarine situations than to explore techniques or specific items of estuarine behaviour in great depth. We also believe that a sound understanding of estuarine physics is a necessary prerequisite for all concerned with their management and control.

There is nothing more frightening to a beginner than an exhaustive reference list and bibliography. The selection that we have made should open the way to the tremendous amount of published work that is now available. Exclusion or inclusion of your favourite book should not be construed as our judgement of its merit!

We are indebted to many people, publishing houses and institutions whose work we have quoted and gratefully acknowledge. We have included much that has not been previously published, mostly of work done by us or with which we have been closely concerned. We would particularly like to thank the following organisations for permission to reproduce their material: Department of Civil Engineering, University of Liverpool and the Mersey Docks and Harbour Company for data concerning the Mersey Estuary; British Transport Docks Board for data concerning the Severn and Humber estuaries; the Chairman and Chief Hydraulic Engineer of Calcutta Port Trust for data concerning the River Hooghly; the Hydraulics Research Station, Wallingford and the Water Research Centre, whose work is acknowledged under the allembracing title of Her Majesty's Stationery Office. 